\title{
Imperial citizenship or else: liberal ideals and the Indian unmaking of
}

empire, 1890-1919

Mark R. Frost, University of Essex

26 Richmond Road, Cambridge, U.K, CB4 3PU

mrfrost@essex.ac.uk

\begin{abstract}
This article examines three connected campaigns for Indian imperial citizenship which spanned the period 1890 to 1919, and their impact on the emergence of radical South Asian anticolonialism. It shifts our focus from individuals and ideologues who sought the status of British imperial citizens, to address the agitations which commenced to attain such a status within a reconstructed British Empire. Specific attention is paid to the conditions which encouraged South Asian patriots to imagine that the ideal of equal imperial citizenship within an imperial federation was a feasible political objective, to the illiberal official retreat from such an ideal, and to the political ramifications of this retreat. In conclusion, this article argues that the quest for Indian imperial citizenship, which spanned the Empire from South Africa to Canada, has been a much-neglected chapter in the evolution of anti-colonial nationalism in South Asia which deserves to be reinserted in the grand meta-narrative of the region's $20^{\text {th }}$ century history.
\end{abstract}

\section{Keywords}

Citizenship, federation, nationalism, loyalty, radicalism, Gandhi, Besant, Tilak

\section{Biography}

Mark R. Frost is Senior Lecturer in Modern History and Head of Department at the University of Essex. He is the author of the award-winning book Singapore: A Biography (2009) and articles in major historical journals such as Past and Present, The American Historical Review, The English Historical Review, Modern Asian Studies and The Journal of Southeast Asian Studies. 
In November 1954, Henry Hopkins, the British Colonial Secretary, remarked during a House of Commons debate:

In a world in which restrictions on personal movement and immigration have increased we can still take pride in the fact that a man can say Civis Britannicus sum, whatever his colour may be, and we take pride in the fact that he wants and can come to the mother country. ${ }^{1}$

Six years earlier, the new British Nationality Act of 1948 made explicit the rights of 'citizens of the United Kingdom and Colonies' and new 'Commonwealth Citizens' to enter and settle in their 'mother country'. ${ }^{2}$ Such rights had theoretically long existed. As the Lord Chancellor reminded Parliament when it debated the 1948 Act, a British subject (when in Britain, at least) could already enter and depart the country at any time, qualify for the franchise, become a member of the Privy Council or of Parliament, join the Civil Service (except in wartime and certain other circumstances) and 'own a British ship'. ${ }^{3}$ Yet, it was only with the same Act's introduction that subjecthood entered the statute book as officially signifying citizenship. As Britain withdrew from its former colonial possessions, the declaration of current and former subjects as British citizens made political and economic sense. Immigrants who could claim Civis Britannicus sum, it was thought, would solve Britain's postwar labour shortage while at the same time shoring up the unity of the nascent Commonwealth from which many would arrive. ${ }^{4}$

The story of what transpired has been well told. Racially-incited violence in 1959 contributed to the British government's imposition of the first checks on Commonwealth immigration in 1962. Further restrictions followed, overseen by both Labour and Conservative governments, under the Commonwealth Immigrants Acts of 1968 and the 
Immigration Act of $1971 .^{5}$ Eventually, the death of Civis Britannicus reached its painful historical postscript with the ignominious 'Windrush scandal' of 2018, during which Commonwealth citizens and their descendants who had settled in Britain were threatened by the Home Office with the removal of their social benefits and deportation. In part as a consequence of a staggering case of administrative amnesia, the British government had stamped out the final embers of a long-held liberal imperial ideal.

Yet this was not the first time that the principle of Civis Britannicus had been trumpeted by politicians before being dismantled and abandoned as they struggled to manage the complex societal changes it engendered. This article explores the causes and consequences of a previous official retreat that occurred through the period 1893 to 1919 when Indians, through a series of globally influential and interconnected campaigns, claimed and sought to exercise their rights as British citizens, only to discover the gulf that lay between liberal imperial rhetoric and reality. Importantly, this quest for imperial citizenship became much more than the elitist aspiration of a moderate Western-educated Indian minority devoted to constitutional modes of agitation - a trivial sideshow when compared with the mass nationalist mobilizations in the decades which followed that sought to end British rule. Rather, as this article will show, the liberal ideal of imperial citizenship played a neglected role in the evolution of Indian anticolonial radicalism, becoming, because of its subversive potential, of great concern to colonial officialdom.

Campaigns for imperial citizenship by colonized peoples have not featured heavily in the study of British decolonization. The scholarship that exists focuses either on the theorizing of imperial citizenship by European ideologues or the invention and performance of imperial citizenship by Western-educated Indian elites. ${ }^{6}$ While this work has recovered ideas once obscured by nationalist emplotments in history-writing, it mostly examines individuals and their aspirations rather than agitations and mobilizations, and thus reinforces 
an impression, as one reviewer has expressed it, that the ideal of imperial citizenship emerged as a fleeting political ambition which never made the transition from inspiring 'individual careers' to 'becoming a viable political program'.

Beyond the British case, however, work by Frederick Cooper, the noted historian of colonial Africa, has begun to reshape the field. Cooper has taken aim at a nationalist historiography that privileges 'a politics of unremitting struggle against an impenetrable colonial edifice rather than forms of political action and claim-making that depended on overlapping idioms and interaction between colonizer and colonized'. For Cooper, both kinds of politics combined to bring down European empires. One form threatened the destruction of colonial regimes through unified (often violent) resistance; the other challenged these regimes "with the possibility that political action would produce concrete gains for different categories of people' and that 'ideologies might be reconfigured', and that notions of the 'politically possible or excluded might shift'.

Cooper's masterful study of decolonization in French West Africa between 1945 and 1960 reveals that conceptions held by both French and African leaders of future imperial citizenship within a Franco-African federation produced tangible political results. The negotiations both sides engaged in to realize their common, yet differently conceived, federation hopes produced a 'succession of concessions and reconfigurations' from which 'France's African population got something quite important - the rights of a French citizen: to free speech, free assembly and equal justice, and, by 1956, to universal suffrage; and to freedom of movement'. 9 The present article builds on Cooper's approach to examine the political struggles waged from at least five decades earlier for equal Indian citizenship within a British-Asian imperial federation. But this study also highlights the striking differences between both cases. By comparison with post-1945 French West Africa, a 'succession of concessions' on the part of the British did not eventuate. Rather, Indian claims for imperial 
citizenship produced a series of illiberal reconfigurations designed to limit the rights of nonEuropeans and jettison any assumptions that they may have had as to how far they shared in such rights.

It is in addressing the political ramifications of this contest, characterized by series of claims made and official retreats, that the present article seeks to break new ground. For, as political leaders from and within India publicly tested the limits of imperial citizenship, threatening to expose the illiberal reality of British imperialism in the process, their quest became itself a radicalizing agent, one conducted with the implicit understanding, which ultimately became an explicit threat, that failure would result in the complete unbinding of the Empire.

Subjects as citizens: rights of belonging to the late British Empire

How, and in what ways, did Indians by the start of the $20^{\text {th }}$ century come to imagine their imperial subjecthood constituted an equal imperial citizenship?

Since the $17^{\text {th }}$ century, the definition of a British subject included all those who owed allegiance to the crown by dint of their birth within the sovereign's domains, a status which the British Nationality Act of 1914 eventually codified to include any person born within the formal British Empire, or who claimed descent from a British subject father, or who became naturalized in Britain or its colonial possessions. As the political scientist Randal Hansen has noted, 'a basic feature of the doctrine underpinning allegiance is indivisibility; all subjects enjoy precisely the same relationship with the monarch and no distinction can be made among them'. ${ }^{10}$ The logical corollary of this, as the young lawyer Mohandas Gandhi was quick to realize, was that privileges enjoyed by some loyal subjects ought to be enjoyed 
equally by others - in particular, the right to move and settle across the British Empire which Europeans had enjoyed from its beginning. As Empire-born Indian lascars discovered, this principle of indivisibility was in practice not always observed. The British Parliament in 1815, to limit their entry into Britain, amended the Navigation Acts to effectively deprive them of their subject status. ${ }^{11}$ Nevertheless, the possibility of equal rights of imperial mobility and settlement returned from the mid- $19^{\text {th }}$ century as Britain adopted a more laissez faire attitude to immigration, as it did to trade.

In 1849, the classical liberal state in Britain repealed the Navigation Acts as the free movement of persons, along with their goods and their ideas, increasingly became a legitimizing trope of mid-Victorian imperialism. The global steamship revolution which took hold from the 1840s resulted in the arrival of many more lascars in Britain and their settlement in port-cities such as Southampton and Liverpool. ${ }^{12}$ Their movement to the imperial centre was one part of a series of migration waves, coerced and voluntary, that occurred within and across the Empire over the remainder of the century and the first four decades of the next. Labour-intensive plantation and mining enterprises, from Trinidad, Mauritius and Ceylon, to Burma, Malaya, Natal and eventually Fiji, drew overseas Chinese and Indian workers. In India, overseas population movements were supported by colonial officials who explicitly maintained the right of Indians to move and settle anywhere across the Empire. As a senior official remarked in 1914, 'the policy of the Government of India has been to contend for the principle that there should be complete freedom for all British subjects to transfer themselves from one part of the Empire to another'. ${ }^{13}$

Grand plans hatched in the imperial capital reinforced this notion of free imperial movement and settlement. At the end of the nineteenth century, former and serving colonial civil servants, supported by their allies in the metropolitan London press, plotted to redistribute India's 'superfluous' population across parts of the Empire whose economic 
development, it was thought, would benefit. Indian subjects were deemed better suited for such work in the tropical climes of Africa than Europeans, and even on occasion spoken of as laying a similar claim to being 'civilizers'. ${ }^{14}$ Meanwhile, the British government displayed its increasing willingness to intervene beyond its borders to protect its far-flung subjects. The most famous formulation of British subjecthood as British citizenship came in 1850, when Lord Palmerston, speaking in Parliament, invoked St Paul's defence in the Acts of the Apostles:

As the Roman, in days of old, held himself free from indignity, when he could say, civis Romanus sum, so also a British subject, in whatever land he may be, shall feel confident that the watchful eye and the strong arm of England will protect him from injustice and wrong. ${ }^{15}$

Palmerston made this statement at the end of his lengthy justification of his decision to send British gunboats to Piraeus to seek redress from the Greek government on behalf of a Gibraltar-born Portuguese Jew called David Pacifico. Three years earlier, Pacifico, who had previously served as Portuguese consul to Greece, had seen his Athens home ransacked by an anti-Semitic Greek mob. Whether or not the 'Don Pacifico Affair' exerted much impact east of Aden, the protection the British Crown afforded its subjects became known of and sought after across the Empire, especially by ocean-crossing traders. Legislation in 1852 that was renewed in 1867 enabled China-born merchants operating in the Straits Settlements of Singapore, Melaka and Penang to apply for naturalization as British subjects. Several did, as British subjecthood provided security for their ships, and an insurance against the vagaries of laws and taxes imposed by the Qing officials they dealt with back in China. At the start of the new century, Straits-born Chinese, all of whom were legally British subjects and some of whom had dealings in China, strove to remind British authorities of their status once it 
appeared that the Qing government might move to claim them as its own nationals under the principle of jus sanguinis. ${ }^{16}$

The notion of imperial citizenship was also encouraged by high-profile British commitments to the future political rights that subjecthood promised. Queen Victoria's 1858 Proclamation to the 'Princes, Chiefs and People of India', which was delivered following the suppression of the 1857 Indian Rebellion, held the crown 'bound to the natives of our Indian territories by the same obligations of duty which bind us to all our other subjects, and these obligations by the blessing of Almighty God, we shall faithfully and conscientiously fulfil.' To commemorate the fiftieth anniversary of this Proclamation, King Edward VII bestowed upon India one of his own. Commenting on the extension of representative institutions of government across the Subcontinent, he noted that 'the time has come when, in the judgement of my Viceroy and Governor General and others of my counsellors, that principle may be prudently extended.' His 1908 Proclamation continued:

Important classes among you, representing ideas that have been fostered and encouraged by British rule, claim equality of citizenship and a greater share in the legislation and Government. The politic satisfaction of such a claim will strengthen not impair existing authority and power. ${ }^{17}$

By this time, official and non-official discussions in the imperial metropolis regularly conflated subjecthood and citizenship, without clearly defining or distinguishing one idea from the other. A prominent imperial commentator observed in 1911 'how loosely' these terms 'are used and interchanged even by the Empire's leading statesmen': 'Such phrases as the "rights of British citizenship," or the "rights of British subjects," or the "liberties" of one or other, are frequently used in protest against legislative or administrative action which the 
responsible parties uphold as perfectly legitimate.' ${ }^{18}$ Of greater importance to Indians who had access to these debates were their countrymen who journeyed to Britain to lay claim to their common rights as British subjects and successfully exercise them. In the 1880s and 1890s, the Liberal Party of Great Britain fielded three Indian candidates in General Elections. The two unsuccessful candidates were the Middle Temple-educated barristers Lalmohan Ghose and W. C. Bonnerjee. The successful candidate was the Parsi merchant, scholar and Indian National Congress leader Dadabhai Naoroji, who was elected MP for Central Finsbury in 1892 on a platform which included his support for Irish home rule. In 1895, the Conservative Party fielded the Bombay-born barrister Mancherjee Bhownagree as the candidate for the North-East Bethnal Green seat in London, which he won and held until 1906. In one of the perversities of this era, Bhownagree was elected on a Tory antiimmigration ticket directed at recent East European Jewish arrivals in London. ${ }^{19}$ For his efforts, The Eastern Argus and Borough of Hackney Times vaunted Bhownagree as 'a true British citizen - acquainted with all those varied conditions of administration which makes the name of Britain great throughout the world today'. ${ }^{20}$

Gandhi's test of imperial citizenship: rights-claiming in South Africa

India's most famous agitator for equal imperial citizenship was Mohandas Gandhi, who took great heart from the electoral success of Dadabhai Naoroji. For his South African crusade from 1893 and 1914, to revoke anti-Indian discriminatory legislation that restricted their immigration, their freedom to move, live, trade and own property across South African territories, and their right (for those few who initially qualified) to vote, Gandhi has been labelled a 'collaborative nationalist'. ${ }^{21}$ A key element within and between these campaigns 
were Gandhi's public avowals of his Empire-allegiance, such as through his organization of volunteer ambulance corps during the Second Anglo-Boer War of 1899-1902 and Zulu Rebellion of 1906. However, the extent to which his loyalty formed a complementary strategy in his overall quest for equal imperial rights has been little discussed. Likewise, the extent to which his efforts drew metropolitan imperial support, coming to be regarded as a test-case of imperial citizenship that would determine the liberal future of the British Empire, has received scant attention. ${ }^{22}$

From the outset, Gandhi built his case for Indian rights in South Africa around the principle of the indivisibility of subjecthood upheld through Queen Victoria's 1858 Proclamation. In his speeches, pamphlets, petitions and newspaper articles, he referred to the Proclamation as 'justly and rightly called the Magna Charta of the Indians' and the Indian's 'Charter of Liberty', ${ }^{23}$ a document that guaranteed Indians 'the same rights and privileges as are enjoyed by Her Majesty's other subjects' under 'the same principle of political equality that enabled Mr Naoroji to enter the House of Commons'. ${ }^{24}$ Victoria had given her royal promise that all her subjects would be treated 'on a footing of equality without distinction of race, colour or creed' ${ }^{25}$ On Gandhi's lecture tour of India in 1896, he announced: 'We belong to the Imperial family and are children, adopted it may be, of the same august mother, having the same rights and privileges guaranteed to us as to the European children. It was in that belief that we went to the Colony of Natal, and we trust that our belief was well founded' ${ }^{26}$

The endorsement which Gandhi's views received in London underlines Nicholas Owen's depiction of the city during this era as the liberal 'soft heart' of the British Empire. ${ }^{27}$ Gandhi's South African campaign was naturally taken up in Westminster by Naoroji and subsequently Bhownaggreee. It was also supported in The Star, a radical newspaper founded by an Irish nationalist which enjoyed a circulation in the 1890 s of roughly $150,000 .{ }^{28}$ In the late-1890s, Gandhi's principal ally was The Times, which gave extensive coverage to his 
agitation. An editorial from 1895 recognized the right of Indians to move to and settle in South Africa, as well as their fundamental importance to its economic development, and called upon the Colonial Office to 'enlighten' the 'ordinary colonist' to recognize 'a fellowsubject in the Hindu or the Parsee' and ensure 'fair treatment is extended to British subjects of whatever colour., 29

Gandhi's key supporter at the Times was Sir William Wilson Hunter, a former Indian civil servant and the author of the paper's weekly 'Indian Affairs' column. Hunter, while he noted that the Proclamation of 1858 was 'no Declaration des droits de l'homme', fully supported Gandhi's stance on the full rights of imperial citizenship it pledged Indians. ${ }^{30}$ Hunter argued that since British officials had "laid down the principle of the "equal rights" and equal privileges of all British subjects in regard to redress from foreign States', the matter was not now 'a question of argument but of race feeling'. The attempt of the Natal authorities to 'deny the rights of citizenship to British Indian subjects' was in addition wrong because 'by years of thrift and good work in the Colony' Indians had 'raised themselves to the actual status of citizens'. In other columns, Hunter expanded his views on the economic case for Indian imperial citizenship: 'It is a mockery to urge our Indian fellow-subjects to embark on external commerce if the moment they leave India they lose their rights as British subjects and can be treated by foreign governments as a degraded and an outcaste race.' He also drew attention to the blood Indian soldiers had sacrificed to win their equal status: 'it would be violation of the British sense of justice to use the blood and the valour of these races in war and yet to deny them the protection of the British name in the enterprise of peace. ${ }^{31}$

Gandhi deployed this metropolitan sanction in a circulatory exchange of print through which the rights-claiming idiom he shared with his metropolitan allies merged. The London newspapers to which Gandhi sent his petitions and pamphlets published summaries of, and commentaries on, his works. Gandhi obtained copies of these through the weekly editions 
these publications sent out to South Africa and other parts of the Empire via the imperial post. He then quoted excerpts from these summaries and commentaries as metropolitan testimonials in his ongoing campaign literature or repeated their language (often verbatim and sometimes unattributed) in his subsequent writings and speeches. Gandhi also circulated these metropolitan testimonials back in India. In this way, he made the congruence of his campaign with the liberal idealism of the imperial metropole a key feature of his platform, one which revealed how out of step the self-governing Colonies of the Empire were with the more enlightened 'mother land'. In this way, too, Gandhi made his campaign a highly-visible example of fellow imperial citizenship in practice, through a political language that transcended racial divisions to reveal the bonds of sympathy between fellow British subjects. $^{32}$

Gandhi and Hunter both understood the Indian agitation in South Africa to have broader, global, political ramifications. Fully cognizant of moves to exclude Indians from entering Australia, New Zealand and Canada, Gandhi spoke of the South African situation as an 'Indian question' which had a 'local as well as Imperial significance'. ${ }^{33}$ Meanwhile, Hunter advised his readers that: 'it is in Southern Africa that this question of their [the Indians'] status must be determined. If they secure the position of British subjects in South Africa, it would be almost impossible to deny it to them elsewhere. If they fail to secure that position in South Africa, it will be extremely difficult for them to attain it elsewhere. ${ }^{34}$ Moreover, both men's demands for Indian imperial citizenship carried a warning and, in Gandhi's case, an implicit threat. In 1897, while Gandhi was delayed in his disembarkation at Durban by an angry white mob, he remarked to a journalist upon the ill 'effects' of South African discrimination: "not only through the colony, but throughout the British Empire, more especially the Indian Empire...it will give the Indians a sort of feeling that will not be got rid of easily'. For the Empire 'to remain in harmony', he argued, Indian rights had to be 
respected. ${ }^{35}$ Subsequently, he warned that the 'exclusive policy' of the self-governing Colonies was 'making a deep impression on the minds of the Indian people, and it cannot but make the task of government in India more and more difficult., 36

The alarms sounded in The Times were, if anything, starker and more portentous. Hunter warned in 1896: 'We cannot afford a war of races among our own subjects'. ${ }^{37}$ A decade later, an especially foreboding editorial in the same paper lamented the 'lapse of years, and perhaps of generation' that 'may be needed to create, if indeed it ever can be created, such a spirit of common Imperial citizenship as will greatly mitigate the combined force of race prejudice and of self-interest'. It went on to describe the 'the graver injury' that the present falsehood of imperial citizenship 'threatens to do us, amongst our Asiatic fellowsubjects, and chiefly among our fellow-subjects in India', when these subjects, through their humiliating experiences overseas, 'discover that the doctrines which they have heard from professorial and official lips are in fact unreal'. Of special concern were the poorer classes of Indians abroad, 'pedlars, small traders, shopkeepers and coolies', who would return home to spread amongst their villages accounts of their mistreatment 'at the hands of British colonists, without interference or protection from the British raj':

A more dangerous body of missionaries of discontent can hardly be imagined...This conflict of rights and of interests is naturally inflaming passions and prejudices in the colonies and in India, which sap and blast the Imperial patriotism that must bind the Empire together, if the Empire is to last. ${ }^{38}$

Ensuring a segregated empire: illiberal reconfigurations at the centre

The imperial dilemma which Gandhi's agitation in South Africa posed Whitehall officials was captured in an internal Colonial Office minute of March 1897, which observed: 'The whole subject is perhaps the most difficult we have to deal with. The Colonies wish to 
exclude the Indians from spreading themselves all over the Empire. If we agree, we are liable to forfeit the loyalty of the Indians. If we do not agree we forfeit the loyalty of the Colonists'. ${ }^{39}$ As Gandhi had committed his energies to his South African agitation in the mid1890s, the British government had knocked back, or made clear it would veto, immigration bills in the self-governing Colonies which explicitly barred Asian immigration on racial grounds. In addition to Natal, Australia and New Zealand had pushed for the exclusion of Indian immigrants, in what has been called a 'prophylactic' measure (given the then lack of such immigration), one demanded by white-supremacist politicians eager to build unifying nationalist platforms based not only on fears of a present 'yellow peril' but a future 'brown' invasion. $^{40}$

At the London Colonial Conference of 1897, Joseph Chamberlain, as Secretary of State for the Colonies, expressed his sympathy 'with the white inhabitants of these colonies which are in comparatively close proximity to millions and hundreds of millions of Asiatics'. Yet he reminded the assembled colonial premiers of the "traditions of the Empire which make no distinction in favour of, or against, race or colour'. His blunt advice was that any exclusion of imperial subjects 'by reason of their colour or by reason of their race...would be an act so offensive to those people that it would be most painful, I am certain, to Her Majesty to have to sanction it'. Nevertheless, Chamberlain indicated that restrictions based on education, along the lines of the Natal Act of 1897, which required immigrants to prove their knowledge of a European language before entry, would be 'absolutely satisfactory'. 41 Thereafter, Australia introduced similar legislation in 1901 which resulted in the country's infamous 'dictation test'. Canada, in 1906, as we shall shortly see, also introduced legislation to exclude the entry of Indian subjects without making race the explicit grounds for this. ${ }^{42}$

In this manner, Chamberlain oversaw a reconfiguration in official thinking regarding Civis Britannicus to accommodate race feelings in the Empire's settler colonies. However, 
these colonies' illiberal influence did not end there. At the 1907 Colonial Conference, the Australian and New Zealand premiers resorted to bullish reassertions of their white-only political visions as if resentful of earlier Whitehall efforts to muzzle them. Alfred Deakin, the Prime Minister of Australia, announced that he was 'determined to have a white Australia', and 'keep it white': 'we will have a white Australia, cost us what it may. We are anxious to let everyone know it'. Joseph Ward, the New Zealand premier, proclaimed that 'New Zealand is a white man's country, and intends to remain a white man's country; we intend to keep our country for white men by every effort in our power' ${ }^{43}$ When the matter of Civis Britannicus was debated, these leaders, along with the representatives of South Africa's Transvaal and Cape Colony, pushed for what was, in effect, a two-tiered British subjecthood which accorded equal rights to white subjects but withheld them from non-Europeans.

The catalyst for this reconfiguration were anomalies in the imperial system of naturalization which meant that, owing to differing criteria applied across the Empire, a naturalized British subject in the colony where they had been granted naturalization did not enjoy it in other colonies. The draft bill intended to resolve this issue generated anxiety amongst colonial premiers because it potentially enabled 'coloured' immigrants naturalized in parts of the Empire, such as Britain and the Straits Settlements, where exclusion on racial grounds was not in force to legally proceed to enter and settle in the self-governing Colonies. Prime Minister Louis de Botha of the Transvaal requested that naturalization granted in one colony 'should have effect beyond the borders of such Colony only when granted to a person of European birth or descent.' Dr Thomas Smartt, the Cape Colony Commissioner of Lands and Public Works, summed up the overall opinion of the Conference when he stated that it supported the principle that naturalized British subjects should 'have all the rights and privileges of British citizenship' in 'any Colony' if the issue of 'the non-Europeans' could be settled. Smartt sought a modification to the government's draft bill so as not to allow non- 
Europeans 'ipso facto, to claim the rights of British citizenship in British possessions.' The Home Secretary Herbert Gladstone replied that although such an amendment would 'simplify matters' it was 'a matter of very considerable difficulty'. ${ }^{44}$

The issue lay unresolved until the 1911 Imperial Conference, which Winston Churchill attended as Home Secretary. When the Dominion delegates returned to discuss Empire-wide naturalization, Wilfred Laurier, the Canadian Prime Minister, affirmed his support for the principle of 'a British subject anywhere, a British subject everywhere...In other words, civis Britannicus is civis Britannicus not only in the country of naturalization, but everywhere'. Laurier then subsequently admitted that 'the colour question' was 'really the true difficulty at the bottom of every mind here, that you may naturalise a class of subject generally undesirable.' Joseph Ward registered New Zealand's support for the ideal of common imperial citizenship as long as it did not impinge on her power to exclude Asian imperial subjects. F. S. Malan, the Minister of Education for South Africa, also gave his support, provided local legislation continued to prevent the full transfer of the rights of Civis Britannicus from the 'country of naturalization' to 'every other part of the Empire'. Malan's reformulation of Civis Britannicus was a restatement of the two-tiered notion of imperial rights aired at the 1907 conference, delivered with an Orwellian twist: 'A British subject anywhere in the Empire is a British subject everywhere in the Empire, but you do not necessarily give him all the rights of a British subject in all parts of the Empire. ${ }^{45}$

Churchill's solution to the 'colour question' was, like Chamberlain before him, to transform it into an ostensible matter of class. He likened the autonomy of the Dominion governments to differentiate between imperial subjects to that which the British government exercised when it distinguished 'between different classes of white British subjects. We do not, for instance, put peers on the register for voting; and there are many distinctions which you draw in the Colonies.' Happy with this formula, the Conference agreed to the resolution 
that 'the effectiveness of local law regulating immigration and the like or differentiating between different classes of British subjects' would be assured, a stipulation that was entered into the statute books as part of the British Nationality and Status of Alien Act of $1914 .^{46}$

However, the Conference's deliberations upon Civis Britannicus did not pass without an intervention from a concerned India Office. Lord Crewe, the Secretary of State for India, pleaded with the assembled delegates for their governments to show a more 'accommodating and friendly spirit' toward Indian immigration. In recognizing their 'undoubted liberty' to determine 'the rules of their own citizenship' and immigration policies, Crewe conceded that the 'natural right' of every British subject 'to travel or still more to settle in any part of the Empire' was no longer tenable. Yet he warned of the momentous political stakes in play surrounding 'this difficulty between the white races and the native races' that threatened 'not merely the well being, but the actual existence, of the Empire as an Empire'. Crewe maintained that the 'question' of 'Indian disability in any part of the British Empire' was in India one that united 'all classes and all creeds and political schools', both loyal and antiimperial. It was a particular asset to the latter because it put in their hands 'a weapon which they are not slow to use in attacking us. If, they ask, Indians are to suffer from disabilities in various parts of the Empire, what good is the British connection at all? ${ }^{47}$

Crewe addressed the Conference with Gandhi's ongoing South African agitation clearly in mind. Three years later, Gandhi concluded this campaign, having launched his final satyagraha to mobilize Indian indentured labourers as well as Indian women. While his experiments with non-violent mobilization were certainly a success, his agitation achieved only a partial victory for Indian imperial rights. The South African Indian Relief Act of 1914, which officially recognized Indian marriages, abolished the poll tax on Indian settlers, eased certain restrictions on their internal movement, and permitted educated Indians to immigrate, may have been applauded by Gandhi as another 'Magna Carta' of Indian liberty. ${ }^{48}$ Yet 
Indians in South Africa still remained restricted in their purchase and ownership of property, in where they could live and trade, and they were still denied the franchise.

\section{Gurdit Singh and the Komagata Maru saga: a second test of imperial citizenship}

No sooner was Gandhi's quest for imperial citizenship in South Africa winding down than another campaign erupted, which in a similar vein threatened to expose the falseness of liberal imperial pretensions. In March 1914, the Singapore-based Gurdit Singh, a wealthy Sikh involved in the labour-contracting business, chartered the Komagata Maru, a Japaneseregistered steamer, to bring 376 would-be Indian migrants, 24 of whom were Muslims, 12 Hindus and the remainder Sikhs, into Canada through Vancouver. ${ }^{49}$ Canada had been slower to legislate to exclude Indian imperial subjects than Australia, New Zealand and South Africa. In 1906, however, as Indian immigration grew, the government enacted a continuous journey requirement that prohibited entry to immigrants who were not arriving directly on through tickets from their country of nationality or domicile. These restrictions, which also required that Indian immigrants had in their possession at least 600 rupees to qualify for entry, were imposed by the Canadian authorities in the full knowledge that no such direct passages existed between India and Canada. In 1909, one year after their implementation, Indian arrivals plummeted from the previous total of 623 in 1908 to $6^{50}$

Gurdit Singh recalled that at a Sikh 'sabha' he had attended in Hong Kong, having arrived in the city in December 1913, he was challenged to help his Indian brethren. In response he hatched a plan to 'vindicate our right of entering Canada' by chartering a steamship 'to fulfil the provisions of the existing law' requiring continuous passage, and by raising 10,000 Canadian dollars 'to be deposited in a Canadian Bank for the sureties of every individual of our community intending to land there'. ${ }^{51}$ Singh was seemingly encouraged by 
the fact that in November 191356 Indian passengers aboard the Panama Maru steamer had gained entry to Canada by successfully appealing their case against the legislation designed to exclude them,. ${ }^{52}$ Yet their success merely led the Canadian authorities to re-write their immigration regulations more tightly. When, in late-May 1914, the Komagata Maru arrived in Vancouver waters, the Canadian authorities prevented it from docking. After a two-month ordeal which drew international attention, the ship and its passengers were escorted out of harbor by gunboats of the Royal Canadian Navy and forced to sail back to Calcutta.

Gurdit Singh clearly intended his voyage to be a test of imperial principles from the outset, one that would have, whichever way the result went, produce a significant political impact. In his personal account, he described his mission as 'a test of the sincerity of the Government in framing the rules. If we complied with all the provisions...it was up to the Government to permit us to land and prove itself to be just and fair. ${ }^{53}$ In the Punjabi prospectus for the voyage issued in February 1914, he proclaimed himself a champion of Indian rights who would 'fight out this case in the Supreme Court in Canada for the decision in our favour forever. If the Canadian Government will persist, then I will ask the necessary questions from my British Government. I will not return back until the real result will be out ${ }^{54}$ He spoke similarly in an interview with an American journalist conducted on the eve of the Komagata Maru's departure. When his interviewer asked him what would follow if he failed to gain satisfaction from the government of India as well as the courts in Canada, he reportedly responded (with a broad smile, while his companions gathered around him and laughed): "I cannot answer". 55 Critically, from its inception, his voyage was also understood by others in the same vein. Ahead of his Vancouver arrival, Canadian journalists, having received London cables which relayed German reports of his intentions, sarcastically referred to his voyage as Gurdit Singh's 'great experiment'. ${ }^{56}$ The British Ambassador to Japan, where the Komagata Maru stopped en route, reported back to the Foreign Office 'of 
the departure of 300 British Indians for Canada, to test the Immigration Laws of British Columbia'. 57

Indian responses to the plight of the Komagata Maru's passengers on their arrival iN Canadian waters emphasized the abrogation of their rights as imperial citizens (and so revealed that the illiberal reconfiguration of Civis Britannicus secured at the heart of the Empire had yet to filter through to, or be acknowledged in, the periphery). Lahore's Indianowned Tribune newspaper, conscious of 'an opinion' in British Indian circles that the '400 Hindus' onboard 'have deliberately been courting trouble' asked: 'But what about the rights of Indians as British subjects?' ${ }^{8}$ The London All-India Moslem League, in a protest delivered directly to the Colonial Office, warned of the 'intense feeling of indignation' that was brewing against not only Canada but the Imperial Government for the failure to protect 'the interests of His Majesty's Asiatic subjects who, by right of imperial citizenship, consider themselves as much entitled to travel and settle in different parts of the Empire as the King's British or Colonial subjects. ${ }^{59}$

The official British response was indicative of the anxieties that had been brewing since the commencement of efforts to reconfigure Civis Britannicus. In early-June 1914, the India Office cabled the Government of India for information as to 'how Indian opinion views present incident and its significance, as compared with the South Africa question' ${ }^{60}$ Viceroy Hardinge was informed by a senior member of his Council that although the impact of Gandhi's South African agitation in India was 'certainly more acute [...] I doubt if it involved such dangerous issues'. Particularly concerning was 'with what damaging effect the exclusion from another part of the Empire of Sikhs - men of a martial race that has done so much in the military service of the Crown - can be turned against us. ${ }^{61}$ Hardinge, in his cabled reply to Whitehall, played down the potential for widespread agitation when compared with the 'South Africa question' while recognizing the threat to British authority in the Sikh- 
dominated parts of the Punjab. ${ }^{62}$ Nonetheless, in a private letter he sent to Crewe at roughly the same time, he expressed his anxiety at the deteriorating imperial situation regarding Indian emigration which appeared 'to daily grow worse': 'Canada, the United States and New Zealand are all on the point of legislation against the admission of Indians. This will make our position here very difficult, unless we are able to find, and you to support, some system of reciprocity. ${ }^{, 63}$

Through June and July, the situation at Vancouver produced the agitation in India that many British observers had expected. Protest telegrams, petitions and memorials were sent to the Government of India (in most cases, being personally addressed to the Viceroy); the bulk of these arose from meetings held in towns and cities across the Punjab. Provincial colonial officials were dispatched to investigate and reported back on the attendance at these protest meetings (typically no more than 500), their 'constitution' (in terms of the social background of the leading agitators), and the associations and individuals who had given them their support. Greater official attention was given to protestors of 'social standing', who were understood to carry greater local influence and the involvement of students was carefully monitored. In contrast, the participation of petty shopkeepers, traders and other less-educated classes was deemed of lesser concern. The owner of 'a small soda water factory' who convened a protest meeting in the temple town of Tarn Taran was adjudged 'of no social or political importance'; the organizer of a meeting in Chandigarh, a 'wood, grass and lime contractor' who held 'the State gardens at Pinjaur on contract', was dismissed as 'a man of no particular position, with a tendency to self-advertisement' ${ }^{64}$

Yet the participation of these humbler classes is especially interesting for it hints at how far Gurdit's Singh's test of imperial citizenship stimulated, via provincial temple and social welfare associations and the Punjab's Western-educated elite, the spread of a unifying rights-claiming idiom. The resolution of the Sri Guru Sabha in the strategically important 
military town of Bannu requested the Government of India to intervene to secure 'the most elementary rights of all British subjects to have free access to all parts of the Empire' ${ }^{65}$ The Khalsa Diwan of Ambala City, another strategically important military town, reminded the Viceroy that 'Indians are citizens of the British Empire and as such ought to be allowed an unobstructed right to live in any part of the British Empire' ${ }^{66}$ As well as difference of class, the support for Singh's Canadian mission on occasion transcended religion. A selfproclaimed mixed 'mass meeting of Peshawar Citizens of all nationalities' telegrammed the Viceroy to register the common Muslim and Sikh distress at 'Indian brethren who are suffering hardships in claiming their legitimate rights of entry into Canada' ${ }^{67}$

Official fears that Singh's test of imperial citizenship would radicalize various classes of Indian opinion were realized on the Komagata Maru's return. Soon after the ship departed Canadian waters, prominent Indian businessmen and educators based on the Pacific Coast put their names to a pamphlet entitled An Open letter to the British Public from the Hindustanis of North America. In what the Vancouver Province newspaper labelled a 'veiled threat', they warned of Sikh desertions in Britain's Indian army and police force once those aboard the Komagata Maru shared their experiences with their brethren back home. ${ }^{68}$ When the ship docked at Budge Budge, near Calcutta, on 29 September, and British officials tried to herd its passengers onto a train headed to the Punjab, violence erupted which saw 18 passengers shot dead. ${ }^{69}$ As has been well studied, the revolutionary Indian Ghadar party capitalized on the voyage's dramatic failure to rally Indian opinion in both North America and north India behind its call for an Empire-wide rebellion during World War One. ${ }^{70}$

For its part, the Government of India dealt with Indian claims to equal imperial citizenship in a way that, especially once war had broken out, only exacerbated the Punjab's lurch towards radicalism. The official attitude to such claim-making was revealed by the Special Tribunal which investigated the Lahore Conspiracy (as the failed Ghadarite rebellion 
of 1915 became known). A significant aspect of its findings concerned its interpretation of a public meeting in Lahore in August 1913 which had protested Canada's immigration restrictions well before Gurdit Singh launched his ill-fated voyage. The tribunal did not find the meeting seditious, regarding there to be 'nothing illegal in representing grievances', but it noted that 'an atmosphere of intemperance was most certainly created' through the impassioned language and 'words of hyperbole' that some speakers employed, and which in hindsight encouraged 'more violent spirits in the career of deplorable crime which they embarked upon'. The Tribunal's overall conclusion was that constitutional agitation 'may easily drift into intemperate agitation, intemperate agitation into sedition, and sedition into active revolutionary methods ${ }^{71}$. Such a view informed the wartime deliberations of the government that resulted in the infamous Rowlatt Act of $1919 .{ }^{72}$ Fearful of the 'drift' from legitimate claim-making into outright rebellion, Britain's imperial state elected to impinge on the rights of Indians further, rather than address what it previously recognized to be their legitimate grievances.

Federalist visions of imperial citizenship: the Home Rule for India campaign

Any examination of the South Asian quest for imperial citizenship would remain incomplete if it did not mention one further agitation, which during World War One became the furthest India had come towards nationwide political mobilization. In May and June 1914, Annie Besant, the Irish-English President of the Theosophical Society in India, protested the Komagata Maru incident in London alongside Lala Lajpat Rai, the Indian nationalist who had previously been arrested for sedition. ${ }^{73}$ Besant on the podium, through press interviews and through articles, demanded Indians enjoy their full rights as imperial citizens, as promised by the 1858 Proclamation; she denounced Australia's and Canada's exclusionary 
immigration policies, rejected the 'colour bar' in the imperial civil service, and bemoaned the exclusion of India from Imperial Federation discussions in the capital. In a veiled threat she shared with an Australian journalist, she claimed: 'A rude and sudden awakening must come if Great Britain and the Empire persist in ignoring India's just claims for freedom and equality. They are loyal at present, but existing conditions are straining their loyalty to breaking point.' 74

Meanwhile, Lajpat Rai captured the 'dilemma' in which the Komagata Maru incident placed the British government. In a letter to the London press, he marveled that the Empire was 'on the threshold of a great agitation' amongst a once loyal people, the 'descendants, compatriots and co-religionists' of those who had saved the Empire during the rebellion of 1857, simply on account of these people seeking to act 'in exercise of their rights of British citizenship': 'They [The British Government] want the Indians to believe that they are the equal subjects of the King, but when the former claim their rights as such, they behave as if they have neither the power nor the desire to secure the same for them.' Lajpat Rai wondered aloud whether the fault was not so much the Government of India's 'as of those statesmen who have to reconcile their professions and principles of Liberalism with their policy of subjection'. He nevertheless warned that there was 'no half-way house between democracy and despotism..., especially since the 'desire, the ambition, and the necessity of claiming British citizenship is no longer confined to educated Indians, but is permeating through the uneducated classes and even the masses. ${ }^{75}$

Evidence for his latter claim was eventually provided by Besant's campaign for Indian Home Rule, which she launched from her Madras base at the start of 1914. The campaign's objectives operated at both a high imperial level, in which India took its equal place amongst the self-governing Dominions, and at a grounded local level, in which Indians were educated to behave as a progressive political citizenry. On the one hand, Besant desired 
to achieve self-government for India along the lines Ireland had been promised by the 1914 Government of Ireland Act, which made provisions for an Irish Parliament. She set out her Home Rule plan through 1914 and 1915 as part of the overall 'reconstruction of the Empire' after the War into an 'Imperial' and then 'World Federation'. Her newspapers proclaimed that 'the term Empire has broadened to signify a unification of peoples under a single scheme of government which should allow its co-ordinated parts the widest possible freedom of autonomy'. They challenged the 'individual Britisher' to 'merge his narrow patriotism into a wide internationalism' and the British government to 'evolve a scheme of imperial rule sufficiently plastic to admit of an adequate amount of Self-Government' ${ }^{76}$

On the other hand, within this plan, Besant sought to create an Indian citizenry 'in which each has a voice "with a share of the power of guidance over the things he (or she) understands", In effect, she advocated a gradated form of universal suffrage, which included, as befitted the ideals of a noted British suffragist, the extension of the franchise to Indian women. All Indians of 21 years and older would gain the vote, in the sense that they would elect village (rural) and ward (urban) panchayats [assemblies] vested with local judicial and public works responsibilities. But, 'as the area become more extensive, and the questions arising more complicated, the interests concerned larger and more interdependent... the electorates shall diminish in number, greater age and higher education being demanded as qualifications.'. Sub-district or Taluq Boards and small municipalities would be elected by Indians of 25 years and over who had completed education up to school leaving level. Provincial parliaments would be elected by district councilors and all men and women of 35 years and over who had been 'educated to the graduate level'. The 'United States of India' Beasant envisioned would have a national 'Federal Parliament' whose membership would be elected by the provincial parliaments. This assembly would in turn send elected 
representatives to the 'Parliament of Empire', the highest authority in the coming world federation. $^{77}$

The inclusive scope of Besant's mobilization, especially once she eventually launched her Home Rule campaign as an explicit protest movement in 1916, was similarly ambitious. Local branches of her Theosophical Society located across all three Indian presidencies and several provinces, not to mention the Society's considerable publishing and distribution network, enabled her to attain a geographically impressive all-India reach. Initially, however, the high membership fees of her Home Rule League meant its social composition remained elitist. Besant and her lieutenants similarly directed the League's 'programme' of activism at an educated, and particularly Western-educated, audience. Leaguers were encouraged to discuss Indian self-government with their friends and persuade them to join movement, to collect political facts and opinions, to form debating circles, to organize public lectures, to print and circulate pamphlets, and to collect funds. They were additionally instructed to establish libraries filled with the 'nationalist' writings by Besant herself, and by authors such as J. S. Mill and the Cambridge historian J. R. Seeley (who had vigorously debated imperial federation and whether India could form part of it). ${ }^{78}$ Yet as the movement intensified it captured supporters from beyond this narrow circle. Copies of Besant's Home Rule newspapers were distributed free or for one anna at railway stations. Her New India newspaper, which she published from July 1914 with the slogan (adapted from the Fenians) 'England's need is India's opportunity', achieved a readership of 10,000 and above. ${ }^{79}$ Colonial officials reported that the paper had 'a very wide circulation in rural areas generally and $[\ldots]$ is giving the Home Rule movement a marked impetus among English-knowing people of all classes' with 'a specially large circulation in the lower ranks of Government service." ${ }^{80}$ They became particularly concerned by the circulation of articles from Besant's papers that were published as separate political pamphlets. It was estimated that by 
September 1916 the Theosophical Publishing House had sold more than 300,000 copies of these pamphlets, with titles such as Citizenship, Social Service, Self Government for India and Home Rule and Empire. Many of these pamphlets were published in vernacular editions with simple explanations of the movement's objectives. ${ }^{81}$

Moreover, to an extent that has been frequently overlooked, Besant's agitation strove to influence the future village citizen who formed such a key part of her Home Rule vision. An official government report from the Madras Presidency noted in December 1916: 'there are indications of initiation of a special campaign for village work based mainly on the distribution of vernacular pamphlets and the itineration of Home Rule preachers. Hitherto the district reports have for the most part pictured the Home Rule movements as confined to younger vakils and students in central towns, but in the report from the Guntur district for the past fortnight the collector lays stress upon the activities of the League in the delta villages of the Tesali taluk. ${ }^{82}$ Such village work included the production of posters, illustrated postcards, religious songs adapted for political purposes, and even popular dramatic performances. It was this work which appears to have ultimately prompted the Madras authorities to arrest and intern Besant in June 1917 for sedition. Her arrest only served to further popularize her campaign. ${ }^{83}$ Her interment was protested by public meetings, processions, prayer gatherings, and a Home Rule swadeshi campaign, which eventually combined with metropolitan pressure in Britain to secure her release. By the time Besant was elected President of the Indian National Congress in December 1917, membership of combined Home Rule Leagues across India (despite their high fees) had risen to around $60,000 .{ }^{84}$ More importantly, Besant was able to reflect in her presidential address that Home Rule had become 'so intertwined with religion by the prayers offered up in the great Southern Temples - sacred places of pilgrimage - and spreading from them to village temples, and also 
by its being preached, up and down the country, by Sadhus and Sannyasins ... And that is why I have said that the two words, "Home Rule", have become a Mantram'. ${ }^{85}$

The grassroots nature of Besant's citizenry-making ambitions is especially revealed through the work she and her lieutenants undertook to prepare Indian women for their role as equal imperial citizens. In southern India, women featured prominently in the agitation for her release, thanks largely to the efforts of the Women's Indian Association (WIA), which Besant and her female allies established a month before she was interned. ${ }^{86}$ Stri Dharma, the WIA's multi-lingual English-Tamil-Malayalam (and occasionally Telugu) journal, produced a range of discussions which branch members were encouraged to debate at local meetings. These included female education, 'Citizenship, the duties of men and women to the community', 'Why Indian women should have votes' and 'Women's suffrage' - which discussed, amongst other things, the practical issue of how women in purdah could vote without having to visit polling stations. ${ }^{87}$ A key concern of the WIA leadership was that a lack of political participation by Indian women, given the changes underway in Britain, might present the British Government with a justification for withholding Indian self-government. In part, Besant and her Home Rulers promoted women's suffrage to gain, so Stri Dharma put it, the 'help and sympathy' of 8,000,000 enfranchised English women, and 'a large number of English men also'.88

Two further aspects of Besant's campaign are worth highlighting. The first is the considerable support she received from illustrious one-time 'extremist' Indian patriots, some of whom who had less than a decade earlier derided the moderate nationalist dream of imperial federation as unfeasible. ${ }^{89}$ As we have noted, Lala Lajpat Rai joined Besant's campaign in London in 1914. He then went on to establish the Indian Home Rule League of America in 1917. The equally famous former-'extermist' Bepin Chandra Pal likewise endorsed Besant's vision of swaraj in articles published in her Home Rule newspapers. ${ }^{90}$ Her 
most important ally, however, was Bal Gangadar Tilak, who established his own Home Rule League in April 1916, pushing Besant to launch hers a few months later. Although the two leaders ran their leagues independently, focusing on different parts of the country, both spoke on the same platforms and joined one another's organizations, as did many of their supporters (including the young Jawaharlal Nehru). ${ }^{91}$ As the language Tilak deployed in his Home Rule speeches underlines, he shared the same vision of equal imperial rights for Indians won through their wartime allegiance, and he similarly warned, through a Marathi newspaper, that if Indians did not receive these rights soon 'the Empire would be lost'. ${ }^{92}$

The other striking feature of this mobilization was the continuing role that Indian faith in the liberal 'soft heart' of Empire played within it. That faith was kept alive by the friendships and alliances that Besant, the former British socialist, and her Home Rule allies forged with left wing and liberal metropolitan sympathizers. In London, Pal became a convert to the 'Empire-ideal' whilst a member of the social circle of the prominent newspaper man W. T. Stead, a proponent of imperial federation. ${ }^{93}$ Lajpat Rai met the Labour Party leader Keir Hardy while in Britain, as well as the Liberal (then Labour) politician Josiah Wedgwood, and the Fabians Sidney Webb and George Bernard Shaw (with whom he attended a Fabian summer school). ${ }^{94}$ The climactic moment in Tilak's Home Rule campaign came when he joined Besant in 1918 in London to present India's demand for selfgovernment. In Britain, Tilak made donations to the Labour Party (which had announced its support in principle, for Indian self-government), attended trade union congresses and became friendly with the left-wing leader and imperial federationist George Lansbury, then editor of The Herald. Tilak's plan of action in Britain was for him to work 'among the higher classes of people' while Besant worked 'among the Labour Party and women' ${ }^{95}$

Nicoletta Gullace, in her study of Britain's wartime campaigns for franchise reform, has described the First World War as a 'Great War for citizenship'. It was equally a Great 
War for imperial citizenship with the year 1918 proving to be the apex of Indian Home Rulers' hopes in the Empire's liberal centre. ${ }^{96}$ The Representation of the People Act at that year's start, and the General Election at its end, were eagerly anticipated in India in terms of their Empire-wide repercussions, as the farewell speeches for a Madras Home Rule delegation sent to Britain ahead of Tilak and Besant reveal. Indian Home Rulers expected that the democratic surge transforming the Empire's heart would flow out to the subcontinent, and a victorious British Labour Party to usher in Indian self-government and equal imperial citizenship. The prominent Home Ruler C. P. Ramaswamier announced:

there are two new factors in English politics which are absolutely unparalleled in the history of English politics. One is the rise of English woman as a power in the English world. Six millions' of English women have been enfranchised today, and in the next election the destinies of the Empire will be partly in their hands...[The second new factor was] the great labour democracy, for remember the balance of power is shifting. It is no longer the peer who is cultivating his land through his tenantry that is the centre of gravity today, nor is the Cambridge or Oxford graduate. It is the man who works with his brain and hand that is grasping power in England; and he puts the question what are you doing out in India? ${ }^{97}$

\section{Rights gone wrong: imperial citizenship as a radicalizing agent}

The agitations we have explored were each in their own ways idealistic failures. From late1918 into the following year, the British Labour Party's poor electoral showing at the General Election, the repressive Rowlatt Act, the 'diarchy' imposed through the 1919 Government of India Act, the Paris Peace Conference negotiations, and the shocking, veil-lifting, violence unleashed at the Jallianwallah Bagh in Amritsar on April 13th - all combined to dissolve dreams of equal Indian citizenship within a postwar imperial federation. Nonetheless, this study has posited that such dreams, and the energy and resources directed towards them, need 
to be reinserted in narratives of the Indian unmaking of the British Empire, not least because of the political consequences of their failure.

In James Scott's contestation of Gramscian notions of false consciousness, he summarizes arguments presented by the political sociologist Barrington Moore, writing that Moore 'implicitly asks us to imagine a gradient of radicalism' in the interrogation of the dominant stratum's claim to power by subordinate groups. 'The least radical step is to criticize some members of this dominant stratum for having violated the norms by which they claim to rule; the next most radical step is to accuse this entire stratum of failing to observe the principles of its rule; and the most radical step is to repudiate the very principles by which the dominant stratum justifies its dominance'. ${ }^{98}$ While this linear explanation of radicalism hardly applies universally, it does help illuminate the career of South Asia's most influential anti-colonialist. To an extent that many accounts have obscured, Gandhi's political campaigns between 1893 and 1919 followed Moore's evolutionary pattern. Whereas the tendency has been to emphasize the dark night of the patriotic soul from which Gandhi suddenly emerged following the end of the First World War, into the new revelatory light of purna swaraj (complete political independence), his ideological transition from wartime Empire-loyalist to postwar passive-resistance hero (nervous breakdown notwithstanding) represented less a political volte face more than a clear progression. ${ }^{99}$ As late as mid1918,Gandhi held out hopes for Indian imperial citizenship. He exhorted his 'Sisters and brother of the Kheda district', immediately following his satyagraha there, to enlist in Britain's armies en masse so that Indians, through their sacrifice, would 'secure the rights we want': 'We want the rights of Englishmen, and we aspire to be as much partners in the Empire as the Dominions overseas'. ${ }^{100}$ When in February 1919 he announced his intention to launch a nationwide satyagraha against the Rowlatt Act, he did so still in pursuit of equal 
imperial subjecthood, describing the new legislation as 'destructive of the elementary rights of individuals' and 'subversive of the elementary rights of citizenship'. ${ }^{101}$

The fundamental yet brilliantly simple addition Scott makes to Moore's formulation, one that helps us better understand not only Gandhi but other Indian patriots who pursued imperial citizenship, comes when he argues that in the gradient of radicalism the 'collective insistence, through petitioning, on the "rights" to which subordinate groups feel entitled carries an understood "or else"'. ${ }^{102}$ This understood 'or else' - the threat of more radical action if the principles espoused by the dominant stratum are not adhered to - was an essential element of the linked campaigns we have surveyed from their commencement and in late-1917 might be said to have reached its comic apotheosis. In November of that year, Edwin Montagu, the Secretary of State for India, toured the country to assess its readiness for 'responsible' self-government. Besant reportedly surprised Montagu in his tent while he was dressing, pressed him to take up the offer of a lift in her motorcar (they were both on their way to see the Viceroy), and used their time together to impress upon him that India must be granted full control over its own executive political bodies and finances. In doing so she made clear that for the cause of Home Rule she had been forced to mobilize Indian students. (She had done so, especially in Madras, through her Young Men's Indian Association). Her 'boys' would continue to forsake anarchy and stick to constitutional reform if Home Rule were granted. But if it were not ... she left the rest to Montagu's imagination. ${ }^{103}$

Evidence such as this highlights the historiographical narrowness of certain respected scholars who have criticized research into colonized peoples' aspirations towards imperial citizenship and federation because they represent (in hindsight) allegedly fantastic and unrealistic alternatives to the independent nation-state. Samuel Moyn, albeit with reference to the West Africa context post-1945 rather than our own, has asserted that 'for the history of federalism to be more than trivia, it has to be shown that it was actually possible'. ${ }^{104}$ Richard 
Drayton, likewise writing in response to Cooper's work, has contended that federalism (and the imperial citizenship contained in it) was, owing to the reality of imperial power-relations 'almost from its beginnings a lie', a product of the 'tightly constrained political space of colonialism' and the 'forced poetics' of a subjugated political imagination in which the only avenue available for the colonized was to "do business in the ideological currency of the colonial power'. ${ }^{105}$

Yet such criticism fails to really address Cooper's original and critical point (reinforced in his response to these critics) that the politics of the rights-concerned claimmaker and the politics of the romantic anticolonial revolutionary frequently combined in the process of decolonization, with the former achieving tangible political gains as the latter prepared, sometimes in the wilderness of exile, for the longed-for moment of liberation. ${ }^{106}$ Our earlier South Asian context sheds further light on how these two forms of politics interacted with and complemented one another. It suggests that that the quest for equal Indian citizenship within a future imperial federation contained from the outset the possibility of radical action; that it was a goal understood by both its proponents and colonial officials in terms of it subversive radicalizing potential (should it fail); that some of its proponents mobilized new political groups with that future possibility in mind; and that others (notably the revolutionary Ghadarite party) may have considered it a futile yet necessary pursuit if the truth about the Empire was to be exposed. Imperial citizenship was certainly 'almost from its beginning a lie', but a lie that Indians first would have to comprehend and experience if they were to be liberated from their imperial false consciousness and set on the path of revolution.

In this regard, Drayton is on firmer ground when he suggests that some colonized leaders may have viewed imperial federation and citizenship more as 'tactical goals'. In the South Asian context, it is the exact nature of these tactical goals that needs clarification. British sedition laws undoubtedly made the ostensible Empire-loyalist tone of Besant and 
Gandhi's wartime rights-claiming an attractive proposition - a politics of the feasible, especially for former-'extremists' such as, Lajpat Rai, Pal and Tilak, who might not have fancied, in some cases further, incarceration. ${ }^{107}$ Nevertheless, official British fears of the 'drift' from legitimate claim-making to anti-colonial rebellion meant even such avowedly loyal dissent did not insure against detention. As India's Department of Criminal Intelligence made clear, Besant was ultimately arrested for having spread a theory of agitation in which 'any attack on what was called bureaucracy was permissible so long as it was accompanied by a perfunctory expression of loyalty to the Crown and the British connection.' ${ }^{108}$

More importantly, the imperial rights-claimers we have focused on in the South Asian context did not seek out, nor accept, merely the partial fulfilment of their quest for Civis Britannicus. Up until the very end, they united in their demand for the full 'rights of Englishmen' in what became an increasingly all-or-nothing gamble. ${ }^{109}$ Whether or not the reality of the independent nation-state was inevitable, South Asian campaigns for imperial citizenship and federation force us to appreciate and understand why these were not merely 'hesitations' upon the long road to full independence, but for extended periods the preferred political choice of notable Indian patriots.

\footnotetext{
${ }^{1}$ Quoted in Randal Hansen, Citizenship and immigration in Postwar Britain: The institutional origins of a multicultural nation (Oxford: Oxford University Press, 2000), p. 251.

2 British Nationality Act 1948, available at http://www.legislation.gov.uk/ukpga/Geo6/11-12/56/enacted. Accessed 18 July 2018.

${ }^{33}$ Ann Dummett and Andrew Nicol, Subject, citizens, aliens and others: Nationality and immigration law (London: Weidenfeld and Nicholson, 1990), pp. 138-39.

${ }^{4}$ Hansen, Citizenship and immigration, pp. 55-56

${ }^{5}$ For an excellent account, see ibid.

${ }^{6}$ On the former, see Daniel Gorman, Imperial citizenship: Empire and the question of belonging (Manchester: Manchester University Press, 2006); on the latter see Sukanya Banerjee, Becoming imperial citizens: Indians in the late-Victorian Empire (Durham NC: Duke University Press, 2010)

${ }^{7}$ See Claude Markovits' review of Banerjee, Becoming imperial citizens for H-Asia. https://networks.hnet.org/node/22055/reviews/22198/markovits-banerjee-becoming-imperial-citizens-indians-late-victorian.
} 
Accessed 18 July 2018. Banerjee, however, pays closer attention the political mobilizations for imperial citizenship in her discussion of Gandhi in South Africa.

${ }^{8}$ Frederick Cooper, Colonialism in question: Theory, knowledge, history (Berkeley: University of California Press, 2005), pp. 231-32

${ }^{9}$ Frederick Cooper, Citizenship between empire and nation: Remaking France and French Africa, $1945-1960$ (Princeton: Princeton University Press, 2014), p. 432

${ }^{10}$ Hansen, Citizenship and immigration, pp. 38-39

${ }^{11}$ See Michael H. Fisher, Counterflows to colonialism: Indian travelers and settlers in Britain, 1600-1857 (Delhi: Permanent Black, 2004), pp 169-71

12 Rozinha Visram, Ayahs, lascars and princes: The story of Indians in Britain, 1700-1947 (Abingdon: Routledge, 2015)

${ }^{13}$ Cambridge University Library [hereafter CUL], Hardinge Papers 87, Gillen to DuBoulay, 11 June 1914 , Correspondence with Persons in India, vol. 7, pp. 412-14

14 'Indian Affairs', The Times, 7 April 1896. The claim that Indians might also be 'civilisers' was made by Sir Lepel Griffin while presiding over a meeting of the East India Association that discussed Indian emigration to Africa; see 'India and Africa', The Times 24 June 1896.

${ }^{15}$ Quoted in Gorman, Imperial citizenship, p. 33, n. 69

${ }^{16}$ Mark R. Frost, 'Transcultural diaspora: The Straits Chinese in Singapore, 1819-1918. Asia Research Working Paper No. 10. https://ari.nus.edu.sg/Assets/repository/files/publications/wps03 010.pdf. Accessed 18 July 2018 ; see also Frost, 'Emporium in imperio: Nanyang networks and the Straits Chinese in Singapore 1819-1914', Journal of Southeast Asian Studies 36, 1 (2005): 29-66

${ }^{17}$ See Appendix to His Majesty King George's Speeches in India, $2^{\text {nd }}$ edition (Madras: Natesan, 1911), pp. xvixxvii

18 'Editor's Note' to E. B. Sargent, British Citizenship, an inquiry as to its meaning (London: Royal Colonial Institute, 1911)

${ }^{19}$ Bishopsgate Institute, George Howell Archive, HOWELL/9/4 part 2, election handbill 1895

${ }^{20}$ Quoted in Sumita Mukherjee, "Narrow-majority" and "Bown-and-agree": Public attitudes towards the elections of the First Asian MPs in Britain, Dadabhai Naoroji and Macherjee Merwanjee Bhownaggreee, 18851906, Journal of the Oxford History Society, 2 (Michaelmas 2004): 1-20, 6

${ }^{21}$ David Arnold, Gandhi (Harlow: Longman, 2001), p. 52

${ }^{22}$ Arnold in ibid. and Bannerjee's Becoming imperial citizens do not explore these dimensions. Nor do Judith Brown, Gandhi's rise to power: Indian politics, 1915-1922 (Cambridge: Cambridge University Press, 1974); or, more recently, Ramachandra Guha, Gandhi before India (London: Penguin, 2014)

23 'Letter to the Natal Advertiser, 29 Sep 1893' and 'The Indian Franchise', Collected Works of Mahatma Gandhi [hereafter CWMG] (Electronic Book, New Delhi, 1998), pp. 62-63, 283-307. Available at http://gandhiserve.org/e/cwmg/cwmg.htm. Accessed 18 Jul 2018.

24 'Letter to the Natal Mercury, 2 Sep 1895', ibid. pp. 269-70

25 'Interview to the Natal Advertiser, 13 Jan 1897', CWMG 2, pp. 1-9

26 'Speech at meeting, Madras, 26 Oct 1896', CWMG 1, 1896, p. 426-48, 437

${ }^{27}$ Nicholas Owen, 'The soft heart of the British Empire: Indian radicals in Edwardian London', Past and Present 220, 1 (2013):143-84

28 'The Indian Franchise'; see also Richard Simms, 'In memory of The Star (1888-1960)', An Index to the Fiction Published in The Star website. http://thestarfictionindex.atwebpages.com/the.htm. Accessed 18 Jul 2018

${ }^{29}$ Editorial, The Times, 30 Aug 1895

30 'Indian Affairs', The Times, 24 Jun 1895

${ }^{31}$ See Hunter's 'Indian Affairs' columns in The Times, 4 Sep 1895, 27 Jan 1896, and 24 Jun 1895

${ }^{32}$ See, inter alia, Gandhi's, 'The Indian franchise'; also 'Memorial to Natal Legislative Assembly', 'Memorial to J. Chamberlain', and 'The grievances of the British Indians in South Africa: An appeal to the Indian public', CWMG 1, pp. 328-32, 337-55, 359-407

33 'Letter to the Natal Mercury, 2 Sep 1895'

34 'Indian Affairs', The Times, 16 Mar 1896, original italics.

35 'Interview to the Natal Advertiser, 13 Jan 1897'

36 'India makes the empire', Indian Opinion 20 Aug 1904, reprinted in CWMG 4, pp. 52-53

37 'Indian Affairs', The Times, 27 Jan 1896

${ }^{38}$ Editorial, ibid., 10 Nov 1906. This editorial was prompted by the failure of Gandhi's deputation to Whitehall, in protest at the implementation of the Transvaal Act, to draw anything more than private apologies and official handwringing. 
${ }^{39}$ Quoted in Roger Daniels, 'The growth of restrictive immigration policies in the Colonies of Settlement', in Robin Cohen (ed.), The Cambridge survey of world migration (Cambridge: Cambridge University Press, 1995), p. 40

${ }^{40}$ David C. Atkinson, The burden of white supremacy: Containing Asian migration in the British Empire and the United States (Chapel Hill, NC: University of North Carolina Press, 2016), pp. 19-48

${ }^{41}$ The National Archives CO 885/6/30, C8596, 'Proceedings of a |Conference between the Secretary of State for the Colonies and the Premiers of the Self-Governing Colonies at the Colonial Office London, June and July 1897', pp. 13-14

${ }^{42}$ Dummett and Nicol, Subjects, Citizens, pp. 120-21; Atkinson, The burden of white supremacy, pp. 43-48

${ }^{43}$ Minutes of Proceedings of the Colonial Conference, 1907. Cd. 3523 (London: HMSO, 1907), pp. 175-6, 53839

${ }^{44}$ Ibid., pp. 178-82, 534-40

${ }^{45}$ Minutes of the proceedings of the Imperial Conference, 1911. Cd. 5745 (London: HMSO, 1911), pp. 249-56, 262

${ }^{46}$ Ibid., pp. 257, 270

${ }^{47}$ Ibid., pp. 394-99. Crewe's warning received short shrift from the Dominion leaders. Laurier claimed that the entry of cheap Indian labour to Canada was so potentially disruptive to local labour conditions that it was, in fact, the real threat to imperial unity. Lee Batchelor, the Australian Minister for External Affairs argued that 'the mixture of black and white races... would tend to a disunited Empire rather than a united Empire'. F. R. Malan remarked that for South Africa, 'it is not so much a question of labour as a question of self-preservation', by which he meant the demographic survival of a white population already outnumbered by non-Europeans, for whom Indian immigration would pose a further threat. See ibid., 399-410.

${ }^{48}$ Arnold, Gandhi, p. 60

${ }^{49}$ Hugh Johnston, The voyage of the Komagata Maru: The Sikh challenge to Canada's colour bar (Delhi: Oxford University Press, 1979), p.33

${ }^{50}$ Dummett and Nicol, Subjects, citizens, pp. 120-21

${ }^{51}$ Gurdit Singh, Voyage of the Komagatamaru or India's slavery abroad, (Calcutta: Author, 1928), pp.15-16

${ }^{52}$ Johnston, The voyage, pp. 19-23; Steve Schwinghamer “"The Immigration Act a weapon”: Panama Maru and the exclusion of immigrants, 1913'. Canadian Museum of Immigration at Pier 21 website, https://pier21.ca/blog/steve-schwinghamer/panama-maru-and-the-exclusion-of-immigrants-1913. Accessed 18 Jul 2018.

${ }^{53}$ Singh, Voyage of the Komagatamaru, p. 16

54 British Library, India Office Records [hereafter IOR], L/PJ/6/1325, Judicial and Political Department, translation of notice for voyage, Despatch No. 101, 26 Jun 1914, pp.19-20. Italics added.

${ }^{55}$ Quoted in Johnston, The voyage, p. 30

${ }^{56}$ IOR L/PJ/6/1325, Judicial and Political Department, clippings from The Province for 16 and 17 Apr 1914 , Despatch No. 101, 26 Jun 1914, pp. 21-23

${ }^{57}$ IOR L/PJ/6/1325, Judicial and Political Department, Conygham Greene to Foreign Office, 13 May 1914, Despatch No. 141, 7 Aug 1914, pp. 3-4

58 'Four Hundred Hindus', The Tribune, 29 Apr 1914, reprinted in Malwinderjit Singh Waraich and Gurdev Singh Sidhu (ed) Komagata Maru - a challenge to colonialism: Key Documents (Chandigarh: UNISTAR, 2005) p. 83.

${ }^{59}$ IOR L/PJ/1325, Judicial and Political Department, London All-India Moslem League to Colonial Office, 18 Jun 1914, Despatch No. 141, pp. 11-12

${ }^{60}$ CUL, Crewe Papers I.17.12, draft telegram from Crewe to Hardinge, sent 9 Jun 1914

${ }^{61}$ CUL, Hardinge Papers 87, Gillan to DuBoulay, 11 Jun 1914, Correspondence with Persons in India, vol. 7 , pp. $412-14$

${ }^{62}$ CUL Crewe Papers I.17.12, copy of return telegram (written) from Hardinge, received 12 June 1914

${ }^{63}$ CUL, Hardinge Papers 120, Hardinge to Crewe, 11 Jun 1914, Correspondence with the Secretary of State for India, vol. 4, pp. 95-98

${ }^{64}$ IOR L/PJ/6 file 1324, Judicial and Political Department, “"Komagata Maru” Resolutions from Public Meetings in India'. See especially: copy of telegram from Mr Nanak Chand, Chairman, Public Meeting of the Citizens of Lahore, 9 Jul 1914; copy of paragraph 14 of the 'Confidential Weekly Diary' of the Superintendent of Policy, Lahore, for week ending 13 Jun 1914; copy of telegram, dated Tarn Taran 13 Jun 1914; translated note of petition (in Urdu) from Baba Nihal Singh Vedi of Chandigarh (Ambala, Punjab), 2 Jun 1914; report of R. A. Mant (Financial Secretary to Government of Punjab), 18 Aug 1914; report of J. S. Donald, Chief Commissioner of North-West Frontier Province, 31 Aug 1914. See also, J. S Grewal, Master Tara Singh in Indian history: Colonialism, nationalism, and the politics of Sikh identity (New Delhi: Oxford Univ Press, 
2017), pp 73-74 Malwinderjit Singh Waraich and Gurdev Singh Sidhu (eds) Komagata Maru - a challenge to colonialism: Key documents (Chandigarh: UNISTAR, 2005), pp. 56-57.

65 “'Komagata Maru” Resolutions from Public Meetings in India': copy of resolution passed by the Sri Guru Singh Sabha, Bannu, 21 Jun 1914; report of J. S. Donald, Chief Commissioner of North-West Frontier Province, 31 Aug 1914.

${ }^{66} \mathrm{Ibid}$., copy of letter from Sardar Jhanda Singh, Pleader Secretary of Khalsa Miandoab Diwan, 21 Jul 1914

${ }^{67} \mathrm{Ibid}$., copy of telegram from secretary of public meeting held at Peshawar, dated 27 Jul 1914. Colonial officials recorded an actual 'mixed audience' at this meeting of around 250 (see report of J. S. Donald, Chief Commissioner of North-West Frontier Province, 31 Aug 1914).

${ }^{68}$ As quoted in a 'Veiled Threat is made by Hindus', Vancouver Province, 8 Aug 1914, reprinted in Wariach an Sidhu (eds), Komagata Maru: Key documents, pp. 102-3

${ }^{69}$ Johnston, The voyage, pp. 92-103

${ }^{70}$ Maia Ramnath, Haj to utopia: How the Ghadar movement charted global radicalism and attempted to overthrow the British Empire (Berkeley: University of California Press, 2011) pp. 48-9; Waraich and Sidhu (eds), Komagata Maru: Key documents, pp. 235-41

${ }^{71}$ The Special Tribunal; Judgement in Second Supplementary Case Dated $5^{\text {th }}$ January 1917, reprinted in Waraich and Sidhu (eds), Komagata Maru: Key documents, pp. 230-41, 234-35

${ }^{72}$ See especially IOR/V/26/262/2, Sedition Report 1918 (Calcutta: Superintendent Government Printing, 1918)

${ }^{73}$ Both had travelled to London to resolve separate legal actions directed at themselves and their associates.

74 'India and the Empire', The Times, 29 May 1914; and 'India and Australia - an interview with Mrs Annie Besant', The British-Australasian 28 May 1914, reprinted in Annie Besant, India and the Empire: A lecture and various papers on Indian grievances (London: Theosophical Publishing House, 1914), pp. 25-29, 30-39

${ }^{75}$ Lala Lajpat Rai, 'A greater measure of self-government', Daily News and Leader, 10 Jun 1914, reprinted in Besant, India and the Empire, pp. 88-93

76 'The Commonweal of the world: international association 1, The Commonweal, $30 \mathrm{Jan}$ 1914; 'The imperial ideal', ibid., 30 Jan 1914; 'Invitation to conference on the formation of the League for Self-government', ibid., 17 Dec 1915

${ }^{77}$ Annie Besant, India: A Nation - a Plea for Self Government, $1^{\text {st }}$ ed, (London, T. C and E.C. Jack, 1916), pp. 89-91

${ }^{78}$ H. F. Owen, 'Towards nationwide agitation and organization: the Home Rule Leagues, 1915-18, in D. A. Low (ed), Soundings in Modern South Asian history (London: Weidenfeld and Nicholson, 1968), pp. 159-95

${ }^{79}$ J. Ransom, A Short History of the Theosophical Society (Madras: Theosophical Publishing House, 1938), p. 409

${ }^{80}$ Fortnightly report from Madras, 18 Dec 1916, quoted in Brown, Gandhi's rise to power, pp. 27-28

${ }^{81}$ Owen, 'Towards Nation-wide Agitation'; J. S. Mortimer, 'Annie Besant and India, 1913-1917', Journal of Contemporary History 18, 1 (1983): 61-78. The holdings of the Adyar Oriental Library of the Theosophical Society in India include the Home Rule Grantha Mala (Malayalam) Series, published by the Malabar Provincial Home Rule League and the Mahajana Sabha in Calicut.

${ }^{82}$ Fortnightly report from Madras, 18 Dec 1916

${ }^{83}$ Ibid., pp. 27-29; Mortimer, 'Annie Besant and India'; Owen, 'Towards nation-wide agitation'. On the decision to release Besant see Peter Robb, 'The government of India and Annie Besant', Modern Asian Studies 10, 1 (1976): 107-30.

${ }^{84}$ Owen, 'Towards nation-wide agitation'. This figure includes membership of Tilak's Home Rule League, discussed below.

${ }^{85}$ Annie Besant, The case for India - Presidential address to the Indian National Congress, 1917 (London: Home Rule for India League, 1917), pp. 31-32

${ }^{86}$ IOR Mss Eur F341/33, Women's Indian Association: Golden Jubilee Celebration, 1917-1967 (Madras: WIA, 1967), pp. 1-2

${ }^{87}$ D. Jinarajadasa, 'Suggestions for conducting a branch meeting', Stri Dharma, Jan 1918, pp. 7-8; and 'Women's Suffrage', ibid., Jan 1919, pp. 63-64; Mithan A. Tata, 'Why Indian women should have votes', ibid. May 1918, pp. 37-39

${ }^{88}$ Jinarajadasa, 'Women's suffrage'

${ }^{89}$ As Pal pointed out, in a 1907 speech to Madras students: 'if we have the rights of freedom of the Empire as Australia has, as Canada has, as England has herself today, if we, the 300 millions of people, have that freedom of the Empire, the Empire would cease to be British. It would be the Indian Empire and the alliance between England and India would be absolutely an unequal alliance'. Bepin Chandra Pal, Speeches of Srj. Bepin Chandra Pal (delivered at Madras) (Madras: Ganesh, 1907), p.43. 
${ }^{90}$ Bepin Chandra Pal, 'Indian nationalism and the British Empire: 1. Autonomy versus independence', The Commonweal, 28 Apr 1916

91 Owen, 'Towards nation-wide agitation'; A. H. Nethercot, The first five lives of Annie Besant (Chicago: Chicago University Press, 1960), pp. 250-51

92 Bal Gangadur Tilak, Lokmanya Bal Gangadur Tilak, his writings and speeches (Madras: Ganesh, 1920), pp 228-49. On Tilak's veiled threat see V. D. Divekar (ed)., Lokmanya Tilak in England, 1918-1919: Diary ad documents (Pune: Tilak Smarak Trust 1997), p. 41.

${ }^{93}$ Marilyn Lake and Henry Reynolds, Drawing the Global Colour Line: White men's countries and the question of racial equality (Cambridge: Cambridge University Press, 2008), p. 250-51

${ }_{94}^{94}$ Feroz Chand, Lajpat Rai, life and work (New Delhi: Government of India, 1978) pp. 89, 259-61

${ }^{95}$ Divekar (ed)., Lokmanya Tilak in England, pp. 193, 577. On Indian ties with the British Left more generally see Nicholas Owen, The British Left and India: Metropolitan anti-imperialism, 1885-1947 (Oxford: Oxford University Press, 2007), pp. 78-105.

${ }^{96}$ Nicoletta F. Gullace, 'The Blood of our Sons': Men, women and the renegotiation of British citizenship during the Great War (New York: Palgrave Macmillan, 2002), pp. 117-41

97 'The Home Rule League Deputation', New India, 8 Mar 1918

98 James Scott, Domination and the arts of resistance: Hidden transcripts (New Haven: Yale University Press, 1990), pp. 91-92; see also, Barrington Moore, Injustice: The social bases of obedience and revolt [first published in 1978] (Abingdon: Routledge 2016)

${ }^{99}$ Erik H. Erikson, Gandhi's truth: On the origins militant nonviolence, [first published 1970] (New York: W. W. Norton, 1993), pp. 227-393; Arnold, Gandhi, pp. 104-114. An exception is Brown, Gandhi's rise to power, pp. 246-49.

100 'Appeal for enlistment: leaflet No. 1, 22 Jun 1918' and 'Appeal for enlistment: leaflet No. 2, 22 Jul 1918', CWMG 17 , pp. 83-87, 139-42

${ }^{101}$ The Satyagraha Pledge', $C W M G$ 16, p. 297; Telegram to Viceroy, (after) 24 Feb 1919, CWMG 17, p. 299

${ }^{102}$ Scott, Domination, p. 95

${ }^{103}$ Nethercot, First five lives, pp. 269-70

${ }^{104}$ Samuel Moyn, 'Fantasies of federalism', Dissent, Winter 2015.

https://www.dissentmagazine.org/article/fantasies-of-federalism. Accessed 19 Jul 2018

${ }^{105}$ Richard Drayton, 'Federal utopias and the realities of imperial power, Comparative Studies in South Asia, Africa and the Middle East 37, 2 (2017): 401-406

${ }^{106}$ Frederick Cooper, 'Routes out of empire', in ibid.: 406-11

107 The constraints which British official definitions of sedition placed on Indian political language are discussed in Robert Darnton, Censors at work: How states shape literature (London: The British Library, 2014), pp. 11442. However, the motivations of prominent wartime imperial federationists cannot merely be reduced to their desire to operate within colonial laws. For the cosmopolitan idealism which underpinned such dreams see Mark R. Frost, "Beyond the limits of nation and geography': Rabindranath Tagore and the cosmopolitan moment, 1916-1920', Cultural Dynamics 24, 2-3 (2012): 143-58.

${ }^{108}$ Quoted in Richard J. Popplewell, Intelligence and imperial defence: British intelligence and the defence of the Indian Empire (London: Frank Cass, 1995), p. 190

${ }^{109}$ Besant and Tilak's Home Rule alliance ultimately fell apart by early 1919 over the former's eventual retreat from this stance following the release of the Montagu-Chelmsford Report.

\section{Secondary Sources}

David Arnold, Gandhi (Harlow: Longman, 2001)

David C. Atkinson, The burden of white supremacy: Containing Asian migration in the British Empire and the United States (Chapel Hill, NC: University of North Carolina Press, 2016)

Sukanya Banerjee, Becoming imperial citizens: Indians in the late-Victorian Empire (Durham NC: Duke University Press, 2010)

Judith Brown, Gandhi's rise to power: Indian politics, 1915-1922 (Cambridge: Cambridge University Press, 1974)

Feroz Chand, Lajpat Rai, life and work (New Delhi: Government of India, 1978)

Frederick Cooper, Colonialism in question: Theory, knowledge, history (Berkeley: University of California Press, 2005)

Citizenship between empire and nation: Remaking France and French Africa, 1945-1960

(Princeton: Princeton University Press, 2014)

(2017): 406-11

'Routes out of empire', Comparative Studies in South Asia, Africa and the Middle East 37, 2 
Roger Daniels, 'The growth of restrictive immigration policies in the Colonies of Settlement', in Robin Cohen (ed.), The Cambridge survey of world migration (Cambridge: Cambridge University Press, 1995)

Robert Darnton, Censors at work: How states shape literature (London: The British Library, 2014)

V. D. Divekar (ed)., Lokmanya Tilak in England, 1918-1919: Diary ad documents (Pune: Tilak Smarak Trust 1997)

Richard Drayton, 'Federal utopias and the realities of imperial power, Comparative Studies in South Asia, Africa and the Middle East 37, 2 (2017): 401-406

Ann Dummett and Andrew Nicol, Subject, citizens, aliens and others: Nationality and immigration law (London: Weidenfeld and Nicholson, 1990)

Erik H. Erikson, Gandhi's truth: On the origins militant nonviolence, [first published 1970] (New York: W. W. Norton, 1993)

Michael H. Fisher, Counterflows to colonialism: Indian travelers and settlers in Britain, 1600-1857 (Delhi: Permanent Black, 2004)

Mark R. Frost, 'Transcultural diaspora: The Straits Chinese in Singapore, 1819-1918. Asia Research Working Paper No. 10. https://ari.nus.edu.sg/Assets/repository/files/publications/wps03 010.pdf.

, 'Emporium in imperio: Nanyang networks and the Straits Chinese in Singapore 1819-1914', Journal of Southeast Asian Studies 36, 1 (2005): 29-66

, "Beyond the limits of nation and geography': Rabindranath Tagore and the cosmopolitan moment, 1916-1920', Cultural Dynamics 24, 2-3 (2012): 143-58

Daniel Gorman, Imperial citizenship: Empire and the question of belonging (Manchester: Manchester University Press, 2006)

Ramachandra Guha, Gandhi before India (London: Penguin, 2014)

Nicoletta F. Gullace, 'The Blood of our Sons': Men, women and the renegotiation of British citizenship during the Great War (New York: Palgrave Macmillan, 2002)

Randal Hansen, Citizenship and immigration in Postwar Britain: The institutional origins of a multicultural nation (Oxford: Oxford University Press, 2000)

Hugh Johnston, The voyage of the Komagata Maru: The Sikh challenge to Canada's colour bar (Delhi: Oxford University Press, 1979)

Marilyn Lake and Henry Reynolds, Drawing the Global Colour Line: White men's countries and the question of racial equality (Cambridge: Cambridge University Press, 2008)

Barrington Moore, Injustice: The social bases of obedience and revolt [first published in 1978] (Abingdon: Routledge 2016)

Samuel Moyn, 'Fantasies of federalism', Dissent, $\quad$ Winter 2015. https://www.dissentmagazine.org/article/fantasies-of-federalism.

Sumita Mukherjee, "Narrow-majority" and "Bown-and-agree": Public attitudes towards the elections of the First Asian MPs in Britain, Dadabhai Naoroji and Macherjee Merwanjee Bhownaggreee, 1885-1906, Journal of the Oxford History Society, 2 (Michaelmas 2004): 1-20

A. H. Nethercot, The first five lives of Annie Besant (Chicago: Chicago University Press, 1960)

H. F. Owen, 'Towards nationwide agitation and organization: the Home Rule Leagues, 1915-18, in D. A. Low (ed), Soundings in Modern South Asian history (London: Weidenfeld and Nicholson, 1968), pp. 159-95

Nicholas Owen, 'The soft heart of the British Empire: Indian radicals in Edwardian London', Past and Present 220, 1 (2013):143-84

Richard J. Popplewell, Intelligence and imperial defence: British intelligence and the defence of the Indian Empire (London: Frank Cass, 1995)

Maia Ramnath, Haj to utopia: How the Ghadar movement charted global radicalism and attempted to overthrow the British Empire (Berkeley: University of California Press, 2011)

J. Ransom, A Short History of the Theosophical Society (Madras: Theosophical Publishing House, 1938)

Steve Schwinghamer “"The Immigration Act a weapon”: Panama Maru and the exclusion of immigrants, 1913'. Canadian Museum of Immigration at Pier 21 website, https://pier21.ca/blog/steve-schwinghamer/panama-maruand-the-exclusion-of-immigrants-1913.

James Scott, Domination and the arts of resistance: Hidden transcripts (New Haven: Yale University Press, 1990)

Richard Simms, 'In memory of The Star (1888-1960)', An Index to the Fiction Published in The Star website. http://thestarfictionindex.atwebpages.com/the.htm

Rozinha Visram, Ayahs, lascars and princes: The story of Indians in Britain, 1700-1947 (Abingdon: Routledge, 2015)

Malwinderjit Singh Waraich and Gurdev Singh Sidhu (eds) Komagata Maru - a challenge to colonialism: Key Documents (Chandigarh: UNISTAR, 2005) 
